\title{
Contribuições da festa do Divino Espírito Santo na crença do protestantismo rural
}

\author{
Contributions of the Holy Spirit's festival \\ on the befiefs of the rural protestantism
}

Lidice Meyer Pinto Ribeiro*

\begin{abstract}
Resumo
O protestantismo de missão chega ao Brasil em 1859 com a vinda de Ashbel Green Simonton ao Rio de Janeiro, impregnado da ideologia do Destino Manifesto americano e de uma teologia pré-milenarista. Apesar das diversas tentativas de evangelização, o protestantismo não cresce inicialmente nos núcleos urbanos, mas sim nas áreas interioranas do país. Isto se dá pelas diversas possibilidades encontradas no catolicismo colonizador, destacando-se o caráter lúdico desse, que trouxe consigo as festas do Divino Espírito Santo, da Santa Cruz, dos Reis Magos entre outras e a solidariedade grupal. Este estudo pontua como a mensagem do evangelho protestante se adaptou ao caráter festivo do povo brasileiro, ávido por uma alimentação espiritual simples e direta. O caráter lúdico do catolicismo praticado pelo colono, juntamente com a escassez de párocos criou um terreno propício para a implantação do protestantismo no interior do Brasil, que se amoldou às crenças milenaristas e do sebastianismo presentes no imaginário caipira dando origem às expressões musicais muito presentes no protestantismo rural.
\end{abstract}

Palavras-chave: Protestantismo rural; Pré-milenismo; Festa do Divino Espírito Santo; Sebastianismo; Milenarismo.

\begin{abstract}
Missionary Protestantism arrived in Brazil in Rio de Janeiro, in 1859 with Ashbel Green Simonton, imbued with the ideology of American Manifest Destiny and premillennial theology. Despite several evangelization attempts in urban centers, Protestantism did not grow initially there, but in the interior areas of the country. The Catholic colonization created opportunities there, by stressing the playful nature of religion, in festivals such as Holy Spirit, Holy Cross, and Three Kings, as well as in its communal solidarity. This study points out how the message of the Protestant gospel was adapted to the playful character of the Brazilian people, eager for a simple and direct religiosity. The festive character of Catholicism practiced by the settlers, along with the shortage of priests, created space for the establishment of Protestantism in the interior of Brazil, and allowed it to conform to the millenarian and sebastianist beliefs of the rural people, giving rise to the musical expressions that characterize rural Protestantism.
\end{abstract}

Keywords: Rural Protestantism; Premillennialism; Feast of the Holy Spirit; Sebastianism; Millenarianism.

Artigo recebido em 14 de outubro de 2016 e aprovado em 29 de março de 2017.

* Pós Doutora em Antropologia e História e Doutora em Antropologia Social pela Universidade de São Paulo. Docente do Programa de Pós-Graduação em Ciências da Religião da Universidade Presbiteriana Mackenzie, São Paulo, Brasil. País de Origem: Brasil. E-mail: lidice.ribeiro@mackenzie.br.

Horizonte, Belo Horizonte, v. 15, n. 45, p. 256-284, jan./mar. 2017 - ISSN 2175-5841 


\section{Introdução}

Desde o século XVII já se observava no Brasil a presença de protestantes, mas foi apenas no século XIX que começou a era das missões protestantes. A presença protestante até então era rara e sem muita repercussão social ou religiosa, marcada pela atuação de pastores voltados apenas a prédica a conterrâneos estrangeiros ou a tentativas malsucedidas de implantação como por exemplo através da invasão holandesa.

Ashbel Green Simonton introduziu o protestantismo de missão com sua chegada ao Rio de Janeiro em 1859. Descendente de presbiterianos escocesesirlandeses, nascido em West Hanover, na Pensilvânia, Simonton foi enviado ao Brasil através da Igreja Presbiteriana dos Estados Unidos da América (PCUSA).

Foi a denominação que mais se expandiu no século XIX, principalmente na província de São Paulo, na qual seguindo a trilha de expansão do café, foi favorecida pela pregação de Jose Manuel da Conceição, ex-padre convertido ao presbiterianismo. (MENDONÇA, 1990, p. 35).

Devido à resistência encontrada nas cidades, como Rio de Janeiro e São Paulo, alguns dos primeiros missionários que vieram após Simonton concentraram seus esforços na pregação pelo interior do país, principalmente na região de São Paulo, Minas Gerais e Goiás. "Não lhes restava alternativa a não ser as áreas rurais, distantes fisicamente da Igreja e fora do patrimônio do santo ${ }^{1 "}$ (MENDONÇA, 1995, p. 120) Esta mesma região que Antônio Candido (2001) chamaria de "cinturão de cultura caipira", foi um terreno fértil para o desenvolvimento do presbiterianismo em seus primórdios. Nesta região em especial, formou-se um protestantismo com características próprias, o protestantismo rural (RIBEIRO, 2014). Muitas foram as questões religiosas, sociais e culturais que favoreceram e

\footnotetext{
${ }^{1} \mathrm{O}$ patrimônio do santo de devoção aqui refere-se às áreas do catolicismo patriarcal, onde vigorava o "direito de padroado". Em uma carta do secretário do bispado de Mariana, MG, do final do séc. XIX, lemos: "os fundadores recebiam dos Exmos. Revmos. Srs. Bispos o título de padroeiros dessas capelas, gozando de muitos privilégios, como o de ter capelão, poder nomeá-los entre os sacerdotes aprovados, administrar os bens das capelas, etc., título este de que os fundadores muito se vangloriavam. Era uma espécie de direito de padroado." (RIBEIRO, 2014, p.172)
} 
prepararam o terreno para a semente do evangelho protestante no mundo rural. Para compreendê-las é necessário retomar a formação desta população de características especiais que é o caipira brasileiro.

\section{Formação religiosa do caipira brasileiro}

A colonização do Brasil desde o seu descobrimento ocorreu de forma desorganizada e através de sucessivos ciclos econômicos. Inicialmente, no século XVI o ciclo do pau-brasil, extrativista, que muito pouco contribuiu à fixação de colonos no país. Com a escassez da tão cobiçada madeira avermelhada, foi a vez do ciclo da cana-de-açúcar (séc. XVI e XVII) que trouxe colonos ao nordeste, seguido pelo ciclo do ouro (séc. XVII e XVIII), que favoreceu as bandeiras e entradas para Minas Gerais, Goiás e Mato Grosso, e, finalmente, nos séculos XVIII a XIX, o ciclo do café que favoreceu a permanência de colonos na área do vale do Paraíba, interior de São Paulo, sul de Minas Gerais e Paraná.

Foi nesta área que se fixou uma população de características agrárias, baseada em economia de subsistência, praticantes da endogamia de lugar, e com uma religiosidade rica em práticas e crenças mágico-supersticiosas, que caracteriza o caipira brasileiro.

Na segunda metade do século XIX, a população brasileira, ainda predominantemente agrária, apresentava...uma 'massa de homens livres e pobres', mais ou menos fora tanto do sistema econômico como do religioso, cuja prática religiosa autônoma girava em torno do folclore ibero-católico (MENDONÇA, 1990, p. 136).

Este colono, em sua grande maioria oriundo das terras portuguesas, trazia consigo uma forte religiosidade, porém com características difusas e não sistematizada (MENDONÇA, 1995, p.131). Esta religiosidade levava o colono a, assim que possível, após estabelecer-se, erguer uma capela para seu santo de devoção. Capela esta que em pouco tempo tornava-se o núcleo de uma aglomeração e posteriormente, um bairro rural. O bairro rural era "caracterizado pela capela, 
pela venda e por alguns moradores, constituindo rudimentar centro comunitário" (PEREIRA DE QUEIROZ, 1968, p.109; MENDONÇA, 1995, p.125).

Apesar da presença frequente de capelas nos bairros rurais que se formam na região, a ausência de uma liderança religiosa oficial era marcante. A capela era assim cuidada e mantida pelo seu construtor, que muitas vezes, devido a sua grande devoção ao santo nela entronizado tornava-se também o líder das reuniões que nela viessem a acontecer. Forma-se assim um catolicismo popular de liderança leiga com características muito peculiares.

A teodiceia do homem pobre era difusa, santorial, de certo modo politéica, portanto mágica e com um razoável colorido messiânico. Era uma teodiceia até certo ponto criada e sustentada pelo leigo. O universo ou visão do mundo era tripartdo: terra, céu e inferno ${ }^{2}$. A vida na terra e sua posterior condição (céu ou inferno) dependia da manipulação dos poderes mágicos e da forma de relação com os santos, seja na forma de uma devoção específica e permanente ou numa forma temporária. Era um cristianismo pouco cristológico 3 e coloridamente messiânico. (MENDONÇA, 1995, p. 136).

Estas características peculiares que marcam o catolicismo popular caipira foram forjadas inicialmente no Portugal ancestral. Tendo o colono português vindo de uma terra por diversas vezes também ocupada por povos de origem religiosa dispare, compôs aos poucos uma religiosidade fortemente arraigada a festas ligadas a fertilidade, a manipulação mágica do sagrado através de ex-votos, ladainhas, romarias, novenas e uma crença em uma diversidade de santos, anjos, milagres e de mistérios envolvendo principalmente os sacramentos. É assim que, a maior parte dos elementos religiosos que veio a constituir o catolicismo rural ou rústico já fazia parte da religião popular em Portugal e foram trazidos, portanto pelo colonizador que ao emigrar, levava consigo, além das esperanças em um mundo melhor, as suas crenças religiosas.

\footnotetext{
2 Em alguns casos, esta visão do mundo poderia ser quadripartida, com a presença do purgatório no imaginário católico de raiz. Para compreender esta visão que ocorre a partir do séc. XXVII sugiro a leitura de O Nascimento do Purgatório, de. Jacques Le Goff (1993).

${ }^{3}$ Por estar se formando um cristianismo pouco cristológico no Brasil que vemos as investidas dos Jesuítas para recentralizar a fé em Cristo. Um dos instrumentos utilizados para este fim foi o livro A Imitação de Cristo, de Thomas Kempis 1995 [1441], obra que muito influenciou Inácio de Loyola. (COUTO, 2013).
} 
No território brasileiro, estas crenças e práticas já regadas de superstições e magia foram se moldando a cada necessidade da população e do local de fixação. Sendo o caipira brasileiro um produtor agrícola por excelência, as festas ligadas a agricultura (plantio e colheita) oriundas de Portugal, como a Festa do Divino, foram preservadas 4 , e outras, como a de Santo Antônio ou de São José foram adaptadas a contextos novos, incluindo rezas e práticas para atrair chuva, por exemplo. Maria Isaura Pereira de Queiroz, ao abordar o catolicismo rústico, já apontava para estas transformações e adaptações sofridas no processo da implantação da religião no Brasil:

Do ponto de vista religioso, o povo brasileiro foi obrigado a se adaptar a duas condições fundamentais, desde os primeiros tempos da colonização: quantidade mínima de sacerdotes e falta de conhecimentos religiosos. A adaptação se deu espontaneamente, e se exprimiu numa reorganização e reinterpretação do acervo de catolicismo tradicional trazido pelos colonos portugueses de um lado e, de outro lado, de catolicismo oficial trazido pelos poucos sacerdotes que aqui aportaram. Nesse processo, elementos novos surgiram: elementos antigos ou pertencentes a religião oficial sofreram transformações; dogma e liturgia foram deformados por necessidades locais ou pela imaginação de líderes religiosos inteiramente falhos de qualquer instrução. (PEREIRA DE QUEIROZ, 1968, p. 105-106).

O colono português trazia em si uma alma católica, mas de um catolicismo popular, mais livre e menos dogmático, mas nem por isso menor em fé e devoção. Foi assim que "do ponto de vista da fidelidade às origens portuguesas, o catolicismo popular rural se conservou mais puro do que o das cidades" (PEREIRA DE QUEIROZ, 1968, p.106).

A vida no campo ou na roça, girava em torno de trabalho cooperativo (unidade familiar e mutirão), as fortes relações de parentesco (endogamia de lugar)

\footnotetext{
${ }^{4}$ Festas como a de São Gonçalo, embora proibidas em Portugal a partir do século XVIII permaneceram no Brasil, tendo formas diferenciadas dependendo da região do país. (PEREIRA DE QUEIROZ, 1968, p. 109).
} 
e a forte religiosidade (devoção santorial5 e caráter lúdico ${ }^{6}$ ). "As relações de vizinhança se davam em dois níveis: a troca de favores especialmente de alimentos, e as ocasionais festas, principalmente religiosas que pareciam ser frequentes dados os numerosos dias santificados.” (MENDONÇA, 1995, p.128) As festas do catolicismo popular com suas características sincréticas foram bem estudadas por Pierre Sanchis (1993, 2001) e Lea Perez (2011).

Dentre as crenças fortemente arraigadas na alma do caipira brasileiro estava uma forte mentalidade messiânica e milenarista7. Esta mentalidade tem suas origens no sebastianismo oriundo de Portugal, reforçada no solo brasileiro pelas histórias da terra sem mal ${ }^{8}$ dos indígenas. Mendonça (1995, p. 234) relaciona os movimentos sebastianistas ocorridos no Brasil com as misturas das crenças indígenas e portuguesas: “As longas migrações de milhares de indígenas, anotadas desde o século XVI, em busca de imortalidade e descanso eternos, podem ter alimentado ou oferecido solo propício para diversos movimentos sebastianistas no século XIX, quase todos eles com desenlaces trágicos. " O milenarismo9 préexistente na mentalidade guarani facilmente se mesclou ao sebastianismo português incluso no catolicismo popular. Esta união de imaginários europeuanmeríndio ocorreu principalmente na região do cinturão de cultura caipira,

\footnotetext{
${ }^{5} \mathrm{O}$ catolicismo popular de Portugal tinha como centro o culto dos santos, tendo cada aldeia ou povoado um santo padroeiro, festejado em datas especiais. (PEREIRA DE QUEIROZ, 1968, p.109). No mundo rural brasileiro, semelhantemente, "cada bairro tem seu padroeiro; cada família, por sua vez, entroniza no oratório doméstico seu santo patrono especial, festejado em casa por meio de novenas e ladainhas." (PEREIRA DE QUEIROZ, 1968, p.113).

6 "A festa religiosa é da mais alta importância no meio caboclo brasileiro: trata-se da maneira tradicional de festejar o patrono local. É preciso que este não possa se queixar dos fiéis, pois caso contrário, vingar-se-á enviando secas prolongadas, inundações, nuvens de gafanhotos, provando que não se acha satisfeito com o tratamento que lhe tem sido dispensado. $O$ santo, porém, tem também seu temperamento e seus caprichos; zanga-se muitas vezes sem razão, malgrado o excelente tratamento de seus devotos. Estes, então, exercem represálias: exilam-no para uma capelinha sem importância por acaso erguida nas terras de um dos moradores do bairro, e que serve assim de lugar de castigo; suprimem velas e flores que de ordinário the oferecem; colocam-no de cabeça para baixo dentro de um poço." (PEREIRA DE QUEIROZ, 1968, p.112).

${ }^{7}$ Milenarismo - Dentro da concepção portuguesa, segundo Gandra $(1998$, p. 54) é a doutrina que anuncia a concretização do milenium, isto é, o período de 1000 anos durante o qual o princípio do Mal seria tornado impotente. Constituem características soteriológicas comuns a todos os movimentos milenaristas: a salvação coletiva; terrestre (se realizará à face da terra e não no céu ou outro local distinto deste mundo); iminente (ocorrerá em breve e de modo repentino), total (não consistirá numa melhoria do presente, mas numa total transformação) e, milagrosa (se realizará por meio de intervenção sobrenatural). No contexto norte-americano, porém, o termo apresenta outras qualificações que apresentaremos mais à frente.

8“A terra sem mal tupi-guarani teria existência geográfica e realização histórica. É um lugar acessível aos vivos, aonde seria possível ir de corpo e alma, sem passar pela morte." (NAVARRO, 1995, p.65)

${ }^{9}$ Apesar da crença na terra sem males ser chamada de milernarismo, este é um conceito equivocado pois, os guarani não possuíam na noção de tempo linear, mas cíclico. Logo não havia a possibilidade da noção de um tempo de 1000 anos. Podemos, porém, dizer que o mito da terra sem males assemelha-se ao milenarismo.
} 
formado em consequência da ação dos bandeirantes e do cultivo do café. Nesta região formou-se o primeiro tipo brasileiro, o mameluco, fruto da união "na carne e do espírito” entre portugueses e índias. (RIBEIRO, 1995)

A história do rei português Dom Sebastião, desaparecido na batalha de Alcácer-Quibir (1578) sem que seu corpo nunca tenha sido encontrado manteve acesa a esperança de seu retorno para a libertação de Portugal do domínio de um rei estrangeiro, já que Felipe II, da dinastia espanhola havia sido o sucessor por direito ao trono, dando início a União Ibérica. Este fato trouxe à tona um sentimento de perda, já que era frequente a concepção de Portugal como um povo escolhido por Deus, que estabeleceria o quinto império ${ }^{10}$ na Terra. Tal ideia de instalou no imaginário português desde que D. Afonso Henriques ${ }^{11}$ avistara o Cristo crucificado no céu, na véspera de sua vitória em Ourique, quando então foi fundado o Reino de Portugal (1139).

as condições da vida nacional determinavam a necessidade de uma esperança como de redenção colectiva, sobretudo para muitos portugueses educados na crença da sobrenaturalidade de muitos episódios da nossa história, convictos de que, pelo menos desde Ourique, tinha Deus tomado Portugal como seu povo eleito e assim o exprimira o diálogo de Jesus com D. Afonso Henriques nas vésperas da batalha. (CIDADE e SELVAGEM, 1972, p. 129-130)

A própria memória de D. Sebastião ${ }^{12}$ como um rei muito devoto e celibatário acabaram por aproximá-lo da figura de Jesus Cristo, fortalecendo ainda mais o seu

\footnotetext{
${ }^{10}$ A concepção de Portugal como Quinto Império, muito importante para o sebastianismo, e para a obra de Antônio Vieira, deriva de interpretações do texto bíblico de Daniel 2, acerca do sonho de Nabucodonosor com a sucessão de cinco reinos sobre a Terra sendo que "na época desses reis, o Deus dos céus estabelecerá um reino que jamais será destruído e que nunca será dominado por nenhum outro povo. Destruirá todos os reinos daqueles reis e os exterminará, mas esse reino durará para sempre." (Daniel 2.44). Interpretações hermenêuticas medievais consideravam o primeiro reino como sendo o assírio, o segundo o persa, o terceiro o grego e o quarto o romano. Acreditava-se que a pedra mencionada no versículo 34 e 35 (“...mas a pedra que atingiu a estátua tornou-se uma montanha e encheu a Terra toda." (v. 35b) significava o Cristianismo que se espalharia pela Terra. A partir do século XII, a concepção portuguesa de ser o povo escolhido por Deus coloca em sua responsabilidade a missão de espalhar o cristianismo pelo mundo. Esta noção de responsabilidade pela cristianização do mundo fica bem clara na carta de descobrimento do Brasil.

${ }^{11} \mathrm{O}$ Juramento de D. Afonso Henriques em que relata a visão do Cristo crucificado e a missão recebida pode ser lido na íntegra em CALAFATE, 2012, p. 277 a 279.

${ }_{12}$ Nos Lusíadas, Canto 1, verso 6, Luis Vaz de Camões (2015), publicado originalmente em 1572 expressa toda a esperança da nação portuguesa para com o seu rei Dom Sebastião, então com 18 anos de idade, sobre o seu papel na propagação do cristianismo e implantação do Quinto Reino na Terra.
} 
mito ${ }^{13}$. Para Auerbach (1997, p. 78) "até a morte de um herói numa batalha contra os infiéis era interpretada como uma forma de sucessão" ou de imitação de Cristo, algo buscado desde o período do Novo Testamento. Assim,

foram de fundamental importância para as expectativas e profecias sebásticas, quando muitos portugueses se ressentiam da União Ibérica e esperavam uma transformação política de ordem providencial, ou, mais especificamente, o retorno de D. Sebastião a Portugal na qualidade de messias salvador para, então, promover, em seu governo, uma era de infinita prosperidade, já anunciada no Milagre de Ourique. (DRUMMOND, 2008, p. 66).

Já desde a primeira metade do século XVI as profecias ${ }^{14}$ de Bandarra (15301540) que apontavam para a vinda de um rei encoberto que traria uma era de infinita prosperidade a Portugal e ao mundo foram sendo divulgadas. $\mathrm{O}$ nascimento de D. Sebastião em 1554 trouxe à tona o desejo de que ele seria o rei encoberto, daí ter recebido o título de "O desejado" quando foi coroado aos 15 anos de idade. Após seu desaparecimento em 1578, com a publicação dos escritos de D. João de Castro ${ }^{15}$, a partir de 1603 sobre o retorno de D. Sebastião ou sebastianismo, já existente, conquistou adeptos também dentre os membros da Companhia de Jesus, como o Padre Antônio Vieira. Tanto que "em quase todas as agitações sebastianistas estiveram envolvidos padres e as trovas de Bandarra eram guardadas por prelados.” (FRANÇA, 1997, p. 239).

A desilusão de Alcácer-Quibir, o desaparecimento de D. Sebastião e a ameaça de absorção espanhola constituíram um factor de radicação e de extensão do profetismo português, bem como o exacerbamento do messianismo e do milenarismo que lhe era intrínseco. (FRANCO, 2010, p. 157).

\footnotetext{
${ }_{13}$ Compreende-se "mito como sendo um discurso sedutor que pretende, no quadro de uma coerência transracional e dentro de uma certa lógica, oferecer sentido para fenómenos, acontecimentos e criações da história, estabelecendo um paradigma único de interpretação". (FRANCO, 2010, p.151).

14 "O Profetismo lusitano anuncia a esperança da regeneração da sociedade portuguesa, de uma idade de ouro, da chegada de um messias, de um grande chefe, de um monarca que conduzirá Portugal e a Igreja de Católica às glórias antigas e assegurará o seu triunfo no quadro mundial de acordo com o que se crê estar divinamente predestinado por Deus aquando da fundação do reino de Portugal." (FRANCO, 2010, p. 155)

${ }^{15}$ Os livros atribuídos a D. João de Castro, neto e homônimo de D. João de Castro, vice-rei da Índia são: Paráfrase (1603), Aurora da Quinta Monarquia (1604-1605). Pode-se conhecer parte destes textos em CALAFATE, 2012.
} 
No Brasil, a história de Dom Sebastião foi principalmente reforçada pelo padre Antônio Vieira após o sermão a São Sebastião, pregado na Bahia em 1634. As alusões veladas a Dom Sebastião por meio da história de São Sebastião são diversas, bem como a omissão da palavra "São" dando margem à possibilidade de substituição inconsciente por "Dom”, como no trecho a seguir: “Assim saiu Sebastião daquela batalha, e assim foi achado depois dela; na opinião morto, mas na realidade vivo: opinione mortuum, vivum repertum. “ (VIEIRA, 2014, p. 425). As duas histórias se entrelaçam constantemente, pois D. Sebastião recebe seu nome em homenagem a São Sebastião, por ter nascido no dia deste santo (20 de janeiro de 1554), tendo o papa Gregório XIII o presenteado na ocasião de seu nascimento com uma das supostas flechas que teriam ferido São Sebastião. (cf MACCA e ALMEIDA, 2003, p. 21).

Outro dentre os inúmeros trechos do sermão que traz diversas aproximações mentais com a batalha de Alcácer-Quibir é transcrito abaixo. Nele pode-se intuir a correlação inconsciente das histórias de São Sebastião e Dom Sebastião através das referências as bárbaros (seriam os mouros?), a um tirano (seria o sultão Mulei Moluco ?), a cristandade que chora (uma alusão a Portugal?) e, mais diretamente ao Encoberto da profecia de Bandarra.

\begin{abstract}
Quem não crerá que está morto Sebastião? Assim o creem os bárbaros, que já se retiram; assim crê o tirano, que já está satisfeito; assim o choram os amigos; assim o lamenta a Igreja; assim o geme, e suspira a Cristandade; mas que importa que Sebastião esteja morto na opinião, se estava vivo na realidade? Isto é ser Sebastião o encoberto; porque encobriu a realidade da vida debaixo da opinião da morte: opinione mortuum, vivum repertum. (VIEIRA, 2014, p. 425).
\end{abstract}

O uso das bem-aventuranças no sermão (pobres, que choram, que tem fome e sede de justiça, perseguidos, odiados) apontam para a usurpação da coroa portuguesa pelos espanhóis, os ataques dos hereges (protestantes) holandeses ao litoral brasileiro e a alta tributação imposta pelo governo filipino ao reino português. Vieira termina seu sermão com outra alusão ao "encoberto": "Desta maneira, Santo glorioso, por meio de vosso amparo conseguiremos a bem- 
aventurança encoberta desta vida, até que por meio da vossa intercessão alcancemos a bem-aventurança descoberta da outra.” (VIEIRA, 2014, p. 434)

Seis anos após esta pregação, em 1640, acontecerá a Restauração que deu fim aos 60 anos da União Ibérica e iniciou o governo da dinastia portuguesa de Bragança em Portugal, com D. João IV16 assumindo na mente de alguns portugueses, incluindo o padre Vieira, a figura do encoberto tão esperado. Os livros "Esperanças de Portugal - Quinto Império do Mundo" (1659), “A História do Futuro" (1665), e “A Chave dos profetas" (1681) trazem à tona o Sebastianismo Heterodoxo ${ }^{17}$ de Vieira. Estes escritos se tornam conhecidos tanto em Portugal como no Brasil, para onde retornou em 1681, após os questionamentos da Inquisição sobre suas ideias sebastianistas, tidas como "heréticas ${ }^{18}$ ".

Foi neste período que o Frade da Ordem da Santíssima Trindade, Frei Sebastião de Paiva escreveu o "Tratado da Quinta Monarquia”, datado de 1641, em que defende teológica e filosoficamente o retorno físico do próprio Dom Sebastião para a implantação do Quinto Império Português (CALAFATE, 2012, p.258-262). Tendo sido escrito logo após a posse de D. João IV e o final a União Ibérica, o texto mostra-se como uma resistência a posse do novo imperador, que muitos passaram a interpretar como uma representação simbólica de D. Sebastião:

O sebastianismo de Sebastião de Paiva pode, assim, ser caracterizado como militante, ortodoxo ${ }^{19}$ e integral. Ele apresenta o Tratado da Quinta Monarquia como fundamentada apologia desse posicionamento o qual se consubstancia na resistência à tentativa protagonizada por intelectuais próximos da nova dinastia de reencaminhar a crença sebástica para a adesão ao novo estado de coisas. (FRANCO, 2004, p. 176).

\footnotetext{
${ }^{16}$ D. João IV, D. Teodósio, D. Afonso VI, D. Pedro II e D. João V foram sucessivamente considerados como representações de D. Sebastião pelos sebastianistas heterodoxos.

${ }_{17}$ O Sebastianismo que se originou em Portugal apresenta duas faces distintas: o Sebastianismo Ortodoxo, desenvolvido até o século XVII, que acredita no retorno de D. Sebastião em pessoa; e, o Sebastianismo Heterodoxo, que projeta o retorno de D. Sebastião em outra figura restauradora, representativa de S. Sebastião. (FRANCO, 2004)

${ }^{18}$ As obras completas de Antônio Vieira foram recentemente publicadas sob a organização de Franco e Calafate (2014) onde se pode consultar todo o processo inquisitorial a que Vieira foi submetido e sua defesa. Vale também a leitura dos livros: A Chave do Profetas (FRANCO; CALAFATE, 2014, tomo III, v. V e VI) e a História do Futuro (v. I) para conhecer o pensamento sebastianista de Vieira.

${ }^{19}$ Para definição de sebastianismo ortodoxo e heterodoxo, veja a nota de rodapé 8.
} 
Por ser um texto em linguagem mais hermética e erudita, e com uma posição perigosa na esfera político-religiosa em que surgiu, não foi impresso, mas copiado a mão. Foram, portanto, poucas as cópias deste texto, o que diminuiu muito o seu alcance frente aos textos de Vieira. (FRANCO, 2004, p. 156).

Apesar destes fatos acontecidos do outro lado do Atlântico, no Brasil, o colono caipira, distante dos acontecimentos econômicos, religiosos e políticos da metrópole, mantinha em si a memória viva da esperança de dias melhores cultivada no sebastianismo. Apesar de Vieira em seus textos proféticos e em sua defesa na Inquisição ter se mostrado como heterodoxo, o sebastianismo que chega ao Brasil é um sebastianismo com característica muito mais ortodoxas que heterodoxas.

\begin{abstract}
Vieira operara uma substituição tática, pois o Encoberto era para os primeiros crentes do Bandarra ninguém menos que D. Sebastião, o jovem rei que desaparecera nos areais de Alcácer-Quibir. A este sim, o povo, desconsolado com o desastre nacional, atribuía poderes messiânicos, esperanças tenazes que, passados três séculos, o nosso Euclides da Cunha ainda ouviria da boca dos sertanejos reunidos em Canudos em torno do Conselheiro. (BOSI, 1998, p.13-14).
\end{abstract}

Dentro de sua religiosidade e fé simples, não faltava nas casas o oratório com imagens de santos particulares, velas, orações diárias e reza do terço. As Bíblias eram raras. Sendo a população em sua grande maioria, quando não totalmente, analfabeta, o contato com a Escritura acontecia pela encenação de certos acontecimentos bíblicos principalmente ligados ao nascimento e a paixão de Cristo. Um contato indireto carregado de traços folclóricos como nas festas do Divino Espírito Santo, dos Reis Magos, da Santa Cruz, dentre outras.

\title{
1.1 A festa do Divino Espírito Santo
}

Uma das marcas distintivas da religiosidade do caipira brasileiro evidenciada por Mendonça (1995) é o caráter lúdico que esta possui. A festa está intimamente ligada à utopia: 
O tempo da festa tem sido celebrado ao longo da história dos homens como um tempo de utopias. Tempo de fantasias e de liberdades, de ações burlescas e vivazes, a festa se faz no interior de um território lúdico onde se exprimem igualmente as frustrações, revanches e reinvindicações dos vários grupos que compõem uma sociedade. (DEL PRIORE 2000, p. 9).

É dentro deste contexto de utopia, voltada para um mundo sem privações e sem sofrimento que a Festa do Divino surgiu em Portugal no século XIII e depois, trazida pelo colono ao Brasil, aqui se estabeleceu, se transformou, e resiste, adaptada a mentalidade messiânica do caipira brasileiro.

Muitos atribuem a origem da Festa do Divino às ideias propagadas pelo abade italiano Joaquim de Fiore ${ }^{20}$ (1145-1202). Para ele, a Santíssima Trindade não poderia ser concebida como três pessoas em uma divindade única, mas como diferentes tempos de influência na Terra, sendo o Antigo Testamento o tempo do Pai, o Novo Testamento o tempo do Filho e o tempo do Espírito Santo começando no século XIII, com a escritura de um terceiro evangelho, o Evangelho Eterno. Este evangelho trataria de uma era de alegria, com o fim de todo sofrimento, fartura e justiça (LEFEBVRE, 1983; BRANDÃO, 1978; MARTINS, 2007). O tempo do Espírito Santo "seria a antecipação utópica do reino da plenitude do homem na história, o tempo da sua libertação, o tempo do nascimento histórico dos contrários, em que o bem nasceria das ruínas do mal. " (MARTINS, 2007, p.11) O início da Era do Espírito Santo se daria com o nascimento de um novo líder, assim como a Era do Filho se iniciou com o nascimento de Cristo (MARIANO, 2014, p.36). O líder desta Era levaria paz e harmonia a todos os povos e acabaria com a pobreza e doenças (BRANDÃO, 1978, p.143). Os Franciscanos foram os principais divulgadores das ideias de Joaquim de Fiore nos Açores e colônias portuguesas através das festas em homenagem ao Espírito Santo, que tratavam de forma simbólica o estabelecimento de seu Reino na Terra através da fartura de alimentos, vida de solidariedade e alegria manifesta nas cores das bandeiras, fitas, músicas e danças. A relação da festa do Espirito santo com a feminilidade foi estudada por

\footnotetext{
${ }^{20}$ Para conhecer mais sobre as profecias de Joaquim de Fiore e sua relação com a cultura portuguesa leia FRANCO, 2002, p. 75-94. Para uma maior compreensão da relação entre a relação entre joaquimismo e sebastianismo, leia GANDRA, 1999.
} 
Natália Correia ${ }^{21}$, que também ressaltou o seu caráter social para o desenvolvimento da dimensão comunitária, um sinal profético da comunhão e fraternidade entre os homens.

Talvez por este caráter feminino que a festa encerra tornou-se uma crença popular sua atribuição à rainha Isabel de Aragão, a Rainha Santa, esposa do sexto rei de Portugal, Dom Diniz I, a popularização das festas do Divino Espírito Santo. Famosa pela sua caridade para com os pobres, D. Isabel, devota do Espírito Santo, teria o costume de distribuir pães aos menos favorecidos, o que teria criado o costume de se distribuir pão nas Festas do Divino ${ }^{22}$. Segundo Andrade (2002, p.147)

Preocupada com a pobreza de grande parcela de seu povo, instituiu as Casas de Misericórdia ${ }^{23}$ e, em festa religiosa, depositou sua coroa sobre a cabeça de um dos pobrezinhos; deve-se a ela a distribuição dos alimentos, as características mais tradicionais das Festas do Divino em Portugal, a partir de Alenquer24.

Observa-se na citação anterior como as festas do Espírito Santo e até mesmo as Casas de Misericórdia são erroneamente atribuídas a Rainha santa de Portugal. Isto é propagado pela devoção popular, apesar de já se conhecer a existência de Festas do Espirito Santo desde o século XIII, senda estas praticadas por devotos franciscanos. Pode-se, porém, atribuir a Rainha Isabel a promoção popular destas Festas.

A devoção ao Espírito Santo, provavelmente devido ao seu conteúdo messiânico e utópico se difundiu muito rapidamente em todo o país de Portugal, tornando-se uma das devoções mais populares. Chegou, portanto, ao Brasil com os primeiros colonizadores. Os documentos mais antigos que atestam a realização da

\footnotetext{
${ }^{21}$ Cf. O Espírito Santo Feminino (CORREIA, 1999). Material estudado por José Eduardo Franco. (FRANCO, 2002, p.175 e 2010, p.61).

${ }_{22}$ Mesmo sabendo-se que as festas do Espirito Santo são anteriores ao reinado de D. Diniz e Isabel, sendo estas provavelmente do século XIII, o senso comum continua a atribuir a Rainha Santa, com muitos devotos em Portugal, tanto a criação da festa como a instituição de obras de caridade a ela associadas. (FRANCO, 2002).

${ }^{23}$ A instituição das Santas Casas da Misericórdia, aqui erroneamente atribuída a Rainha Santa, devem-se a Rainha D. Leonor (1498) que, colocou Portugal séculos à frente de toda a Europa em termos de assistência hospitalar (GAMEIRO, 2010, p.183).

${ }^{24}$ Alenquer fazia parte do dote recebido por Isabel por ocasião de seu casamento com o Rei Diniz. Nesta localidade Isabel teria mandado erguer a primeira capela do Espírito Santo em Portugal.
} 
Festa do Divino no Brasil datam do século XVII e XVIII. No Brasil, manteve alguns de seus elementos tradicionais portugueses como o uso da bandeira vermelha que simboliza o batismo de fogo do Espírito Santo e a pomba branca, representativa do próprio Espirito Santo, as fitas coloridas, a distribuição de alimentos, e, a inversão social (representada pela coroação de um imperador menino). Com o povoamento do interior, os demais elementos foram se transformando, amoldando-se às características próprias de cada região. Mas permanece sempre "o sentido utópico da Festa do Divino: a fartura, a alegria, a caridade, o amor, a solidariedade, a religiosidade" (MARIANO, 2014, p. 39).

\section{A pregação protestante no meio rural brasileiro}

Foi assim que, ao penetrar na zona rural do país, os missionários protestantes chegados no século XIX depararam-se com uma religiosidade que trazia em si elementos do catolicismo oficial moldados segundo a cultura caipira abrindo, segundo Mendonça (1990, p.135), brechas para a evangelização: "Se o catolicismo cultural foi um poderoso entrave para a introdução do protestantismo, a religião católica, isto é, as suas projeções institucionais e oficiais, oferecia na época algumas brechas para a 'nova religião'."

As brechas culturais às quais Mendonça se refere podem ser vistas principalmente três áreas: a catequese superficial realizada na colonização católica, o quadro político-religioso que confundia religião com o Estado e a própria condição social em que o caipira vivia. Mendonça correlaciona cinco razões porque a população rural ofereceu pouca resistência a mensagem protestante:

o campo religioso rarefeito, o temor constante da expropriação religiosa, a recusa do padre como sinal desta expropriação, a pobreza do receptor da mensagem protestante e, finalmente, o nomadismo religioso... afiguram se ter sido as pequenas brechas através das quais o protestantismo penetrou na camada pobre da população rural”. (MENDONÇA, 1995, p.146).

O evangelho protestante, portanto, adentra ao meio rural brasileiro como uma proposta alternativa plausível tanto no plano das crenças como no das 
condições de existência. O caipira brasileiro vivia sob o manto do catolicismo. Apesar da escassez de padres 25 a forte religiosidade do colono do interior do Brasil preservou algumas das crenças de forma livre, através de rezas, ladainhas, novenas, romarias e festas conduzidas por líderes leigos, até mesmo por ex-escravos ${ }^{26}$, muitos deles com conhecimento de ervas curativas.

O protestantismo trazido pelos missionários, por sua vez, apresentava um forte teor messiânico, uma influência direta das ideias de destino manifesto 27 e uma forte tendência para o pré-milenismo ${ }^{28}$. Mendonça (1990) mostra que duas correntes de pensamento estavam presentes na pregação dos primeiros missionários protestantes: o pós-milenismo ${ }^{29}$, que trouxe consigo a crença de que era possível construir uma sociedade melhor na terra à espera da volta de Cristo3o e, o pré-milenismo ${ }^{31}$, que trouxe consigo o desencanto com a capacidade humana de inserir o Reino de Deus na terra. Dos dois, porém, na teologia dos norteamericanos em geral o "pré-milenismo ocupava um espaço especial” incorporandose ao pensamento institucional protestante (MENDONÇA, 1995, p. 236 e 237)

Mendonça (1995:121) já diria que "é lugar comum na história do Brasil o mesmo ideal milenarista dos povos ibéricos quanto à colonização de novas terras,

\footnotetext{
${ }_{25}$ O Bispado de São Paulo, até 1892, compreendia o que hoje são os estados de São Paulo, Paraná, Santa Catarina e parte de Minas Gerais. Para atender a toda esta região havia um bispo e poucos padres. Algumas capelas rurais demoraram cerca de 50 anos para serem visitadas por um bispo.

${ }^{26}$ Um dos casos interessantes de igrejas conduzidas por um negro é o ocorrido na cidade de Sorocaba, SP, onde sob a liderança do exescravo João de Camargo foi estabelecida a Capela do Senhor do Bonfim, envolvida em diversas disputas de poder com a Igreja Católica Oficial no início do século XIX. Para ler mais sobre João de Camargo veja: FRIOLI; CAMPOS, 1999.

${ }^{27}$ As igrejas protestantes do Estados Unidos estavam experimentando no século XIX movimentos de "reavivamento espiritual", que tinham como uma de suas ênfases principais a necessidade de converter os pagãos para abreviar a instalação do Reino de Deus, o que desencadeou ali a chamada "Era Missionária".

${ }^{28}$ Para os adeptos da Era Missionária protestante, a cristianização do mundo, à semelhança do sebastianismo português, seria um prérequisito para a Vinda do Reino de Deus, que se iniciaria com a volta de Cristo. Na teologia protestante observa-se a formação de 4 correntes a respeito do milênio: pré milenismo histórico, pré-milenismo dispensasionalista, pós-milenismo e amilenismo. Para conhecer melhor estas correntes teológicas sugiro a leituras do livro "Milênio - significado e interpretações" editado por Robert G. Clouse.

29 "Contrastando com o pré-milenista, o pós-milenista explica que o reino de Deu está atualmente sendo expandido através do ensino e pregação cristãs. Essa atividade fará com que o mundo se cristianize e resultará em um longo período de paz e prosperidade chamado milênio. [...] A igreja se tornará mais importante, e muitos problemas sociais, econômicos e educacionais serão resolvidos. Esse período fecha-se com a segunda vinda de Cristo, a ressurreição dos mortos e o estado final." (CLOSE, 1985, p. 8)

${ }^{30}$ Esta visão se manifesta principalmente na ação educacional dos protestantes e na forte presença no meio intelectual brasileiro além da produção de jornais e de livros.

31 “Os pré-milenistas crêem que a volta de Cristo será precedida de certos sinais como a pregação do Evangelho a todas as nações, uma grande apostasia, guerras, fomes, terremotos, o aparecimento do anti-Cristo e uma grande tribulação. Sua volta será seguida de um período de paz e justiça [o milênio]antes do fim do mundo. (CLOSE, 1985, p. 7-8).
}

Horizonte, Belo Horizonte, v. 15, n. 45, p. 256-284, jan./mar. 2017 - ISSN 2175-5841 
isto é, a implantação do corpus chistianum à semelhança do que foi dito a respeito dos norte-americanos”.

Não é de se estranhar, portanto que, o morador das regiões rurais brasileiras, distante geograficamente e teologicamente da influência dos párocos católicos, reconhecesse na mensagem protestante uma possibilidade de receber um alimento espiritual que satisfizesse sua sede de fundamento religioso. "O meio rural, bem como o abandono econômico e religioso em que vivia a camada da sociedade brasileira que recebeu o protestantismo eram propícios à mentalidade milenarista dos missionários” (MENDONÇA, 1990, p.138)

\subsection{Protestantismo Rural}

O protestantismo rural que se formou na região do cinturão caipira brasileiro apresenta assim uma espécie de relação simbiótica com as crenças do catolicismo de raiz trazido na alma do colono português e traduzido nas manifestações culturais. Podemos desta forma intuir a presença de uma religiosidade popular nos bairros rurais protestantes, que em muitas maneiras se assemelha ao catolicismo popular, mas que também, em muitas maneiras se distancia deste, originando um universo de crenças e práticas único e diferenciado. Surge um sistema mágico-religioso, que apesar de regido por uma religião de características racionalistas, possui um domínio que escapa completamente às representações oficiais: um domínio mágico, autônomo da sociedade caipira brasileira, eivada do catolicismo popular. "O protestantismo rural tem o poder de legitimar a cultura religiosa do lençol caipira ao qual se adaptou, impedindo a constituição de uma cultura ilegítima.” (RIBEIRO, 2009, p. 220)

Do catolicismo popular, o protestantismo rural mantém familiaridade com o sagrado, apresentada pela religiosidade difusa, santorial, politeísta, mágica e “com um razoável colorido messiânico” (MENDONÇA, 1995, p. 135), e o caráter lúdico marcado pelas festas e as relações de compadrio. O fiel converso ao protestantismo 
mantém dentro desta modalidade de crença a busca pela resolução de seus problemas mais próximos, recorrendo não mais aos santos, mas a Deus, para proteção contra a seca, as doenças, raios e tempestades e toda a sorte de infortúnios. A crença na variedade de santos intercessores passa a ser substituída pela crença nas três pessoas da trindade divina, cada qual com uma personalidade própria e voltada para atender a necessidades especificas do caipira. "Ocorre, portanto, uma combinação, onde certas referências bíblicas são selecionadas e reapropriadas pela cultura camponesa, que as relaciona com suas experiências próprias do misticismo da catolicidade rural” (RIBEIRO, 2014, p. 342)

Deus-Pai é presença constante na vida do fiel protestante do mundo rural, acompanhando o homem em todo o seu dia de trabalho, sendo buscado para proteção das aflições e para benção do fruto do trabalho. Deus-Filho, Jesus Cristo é visto como uma pessoa um pouco mais distante, que se aproxima do fiel em momentos específicos da vida, principalmente durante a participação na comunhão dentro da igreja e no momento da morte. Isto pode ser compreendido dentro do próprio catolicismo popular que outorgou a Jesus Cristo o papel secundário e até mesmo derrotista na procissão do Cristo Morto, sublimada nas imagens do Cristo sofredor, presentes em quase todas as capelas, que leva ao fiel um sentimento de pena, compaixão, mas não de vitória. “A pessoa de Cristo (no catolicismo popular) ... não é figura chegada e íntima da vida devocional” (ARAÚJO, João Dias de cit in BOFF, 1974, p. 46) Este distanciamento físico e espiritual de Cristo se perpetua com a mensagem pré-milenista do evangelho protestante que apregoa que o Messias virá instaurar o milênio. Ora, se Ele virá, é porque não está aqui ainda. Logo, no inconsciente deste fiel recém convertido a nova mensagem se firma de forma a considerar o Deus-Filho uma pessoa da trindade mais distanciada que a pessoa do Deus-Pai ou do Deus-Espirito.

Por último, o Deus-Espírito, que desempenha nesta forma de crença uma função de realizador de milagres. É ele que é buscado e que atende ao fiel nas situações mais difíceis da vida humana, no sofrimento da doença e nas chamadas 
“causas impossíveis". É também ação do Deus-Espírito o arrependimento e a conversão humana. É dentro desta perspectiva de um Deus mais próximo do fiel do que o Deus-Filho, que o protestante rural compreende o papel do Espirito Santo em apressar a vinda do Deus-Filho através de uma ação de cooperação com o ser humano. Cabe ao homem pregar o evangelho; ao Espírito Santo cabe realizar a conversão.

O Reino virá por iniciativa divina e não por qualquer esforço humano. $\mathrm{O}$ que compete ao homem não é 'edificar' o Reino, mas estar pronto para a sua vinda sobrenatural mediante o arrependimento e a fé. Para uma sociedade impotente e sem esperança era necessário pregar o arrependimento, a fé e a esperança num mundo compensador para o atual, corrompido e feio. Em suma, o Reino não é um desenvolvimento histórico contínuo; simboliza o fim da era presente, é o 'para lá da história'. (MENDONÇA, 1995, p. 236).

Por outro lado, o messianismo do catolicismo popular está presente na oposição deste mundo, temporário e passível de sofrimentos com o mundo futuro, eterno e perfeito. Todos os sofrimentos da vida presente são interpretados como castigos divinos, mediante aos quais a postura de submissão do fiel pode lhe garantir um futuro melhor na vida eterna. (RIBEIRO, 2009, p. 195).

Podemos perceber, portanto que o clima propício ao messianismo no Brasil rural, com uma população dispersa, sem a presença oficial da igreja, e dentro de um contexto desfavorecido economicamente, abriu caminho para a absorção da mensagem pré-milenarista do protestantismo missionário.

Desta forma, o sebastianismo português e as crenças ligadas à Festa do Divino Espírito Santo não só abriram caminho para a entrada da mensagem protestante no meio rural brasileiro como também se perpetuaram sob uma nova roupagem que fica bem perceptível através da hinologia apreciada até hoje nas igrejas rurais. Mendonça (1995) foi o primeiro a destacar a preferência das populações rurais protestantes pelos hinos de caráter messiânico. 


\subsection{A Hinologia do Protestantismo Rural}

Encontram-se nestes hinos as características básicas de toda mentalidade milenarista: igualitarismo, santidade e perfeição. Estão presentes também os componentes dos mitos da idade do ouro, a ausência de sofrimento e de velhice (MENDONÇA, 1995, p. 239).

Do hinário utilizado no início da evangelização do interior brasileiro, o Salmos e Hinos com Músicas Sacras32, publicado em 1861, cerca de 73 hinos são sobre a volta de Jesus. Podemos perceber assim que realmente, nos primórdios da evangelização no Brasil "havia uma mentalidade milenarista assim como uma expectação milenarista”. (MENDONÇA, 1995, p.239).

Há de se destacar que o mentor deste primeiro hinário brasileiro, o escocês Dr. Robert Kalley, possuía uma grande experiência de vida com o povo português por ter evangelizado a Ilha da Madeira durante 1838 a 1846. Neste período provavelmente tomou contato com as Festas do Divino Espírito Santo, tão ricamente celebradas nas ilhas. Em sua atuação na Ilha de Funchal, Robert Kalley não causou nenhuma ruptura cultural com as tradições portuguesas ali já existentes: construiu um hospital com 12 leitos para necessitados, instituiu uma campanha contra o analfabetismo e criou escolas diurnas para crianças e noturnas para adultos33. O pesquisador Oliveira (2006, p. 107) relata que:

Passado algum tempo, o êxito do seu filantrópico trabalho de médico, pedagogo e missionário, granjeou-lhe vastas simpatias por parte dos populares com quem contactava e a quem dispensava desvelada atenção, e esse reconhecimento verificava-se nas inúmeras adesões às suas ideias religiosas.

\footnotetext{
${ }^{32}$ O primeiro hinário protestante em português foi idealizado pelos missionários Dr Robert Kalley e sua esposa Sarah Kalley, fundadores da Igreja Evangélica Fluminense, organizada em 1858 no Rio de Janeiro. A primeira edição do hinário, publicada em 1861, continha 50 cânticos, sendo 18 salmos e 32 hinos. Posteriormente, a segunda edição foi publicada em 1865 com 25 salmos e 58 hinos. A terceira edição, que apresentava o formato atual, recebeu o nome de Salmos Hinos com Músicas Sacras e foi publicada em 1889, sob a coordenação do filho adotivo do casal, João G. da Rocha.

${ }^{33} \mathrm{O}$ trabalho do Dr Kalley resultou em louvor público em Actas da Câmara do Governo Municipal da Cidade do Funchal, do dia 25 de Maio de 1841, que o nomeava como "o bom doutor inglês» e caracterizava seu trabalho como "esforço filantrópico em favor dos pobres, doentes e analfabetos» (OLIVEIRA,2006, p.107).
} 
Foi no período de estadia na Ilha de Funchal que o Dr Kalley começou a utilizar-se de hinos em português: "Por todos os recantos da ilha se podia encontrar gente que conhecia os 'hinos calvinistas', nome dado à versão métrica dos salmos traduzidos." (OLIVEIRA, 2006, p. 108)

Em 1846, Robert Kalley foi forçado a se retirar das Ilhas34 mas conservou o seu interesse pelas comunidades de origem portuguesa, tendo mantido contato com diversos outros grupos nos EUA e na Ilha da Trindade até sua ida ao Brasil em 1855. Lá, dentro de uma maior abertura para a pregação missionária conseguiu publicar a coletânea de hinos em português sob o nome de Salmos e Hinos.

É temerário fazer afirmativas, mas o certo é que a hinologia trazida para o Brasil parece ter acompanhado a crença messiânica presente nas Festas do Divino em Funchal, adaptada ao pensamento milenarista trazida pelos missionários ao solo brasileiro.

Apesar das diversas denominações que se estabeleceram no Brasil a partir do século XIX35 possuírem algumas visões teológicas diferentes, o uso de um hinário comum acabou por unificar a crença dos fiéis que se identificavam com as letras e com as melodias dos hinos.

Em resumo, o Salmos e Hinos representava, no fim do século XIX, uma coletânea de cânticos que englobava os hinários que foram aparecendo desde o início do estabelecimento institucional do protestantismo no Brasil, isto é, 1855. Representava também, e isto é bastante significativo, o repositório comum de cânticos religiosos da maioria absoluta dos protestantes no Brasil. (MENDONÇA,1995, p. 193).

\footnotetext{
34 “Como seria de prever, não tardaram as reacções adversas a tanto sucesso, por parte de responsáveis das instituições locais políticoreligiosas postas em causa, que começavam a sentir os efeitos da censura subliminar aos órgãos de poder, acusados da precariedade de vida, e a erosão que tomava conta dos fiéis do Catolicismo atraídos, cada vez mais, por práticas religiosas mais próximas das suas vidas. " (OLIVEIRA, 2006, p.108). Assim, devido à pressão exercida por clérigos católicos, Kalley foi preso por seis meses e após vários ataques sofridos por membros da comunidade evangélica e a sua própria casa, decidiu se retirar para a Inglaterra.

${ }^{35}$ Os presbiterianos foram os que alcançaram uma maior área de implantação, por isso são enfatizados neste artigo, mas também há de se ressaltar a presença dos Congregacionais, Metodistas, Luteranos e Batistas.
} 
Abaixo, no Quadro 1, pode-se ver uma comparação entre as letras utilizadas nas populares Festas do Divino Espírito Santo no Brasil e alguns dos hinos do Salmos Hinos utilizado nas primeiras igrejas protestantes:

Quadro 1 - Comparação entre letras de músicas
da "Festa do Divino" e Hinos do "Salmos e Hinos"

\begin{tabular}{|c|c|c|}
\hline Características & $\begin{array}{c}\text { Músicas da Festa do } \\
\text { Divino }\end{array}$ & Músicas do Salmos e Hinos \\
\hline Volta de Jesus & $\begin{array}{l}\text { A Bandeira do Divino36 } \\
\text { No estandarte vai escrito } \\
\text { Que ele voltará de novo } \\
\text { Que o rei será bendito } \\
\text { Ele nascerá do povo }\end{array}$ & $\begin{array}{l}\text { Não Tardará (126) } \\
\text { Cristo mui breve do céu virá, } \\
\text { Pois prometeu e jamais faltará. } \\
\text { Oh! Que alegria, que glória será } \\
\text { Quando Jesus regressar! }\end{array}$ \\
\hline Milênio & & $\begin{array}{c}\text { A Vitória Final (125) } \\
\text { Glorioso, no milênio, vai reinar aqui Jesus, } \\
\text { O Cordeiro que imolaram sobre a cruz; } \\
\text { As nações verão, então, o resplendor do } \\
\text { grande Rei } \\
\text { E eu, por Sua imensa graça, lá estarei. }\end{array}$ \\
\hline $\begin{array}{l}\text { Felicidade } \\
\text { Futura }\end{array}$ & $\begin{array}{l}\text { A Bandeira do Divino } \\
\text { A bandeira acredita } \\
\text { Que a semente seja tanta } \\
\text { Que essa mesa seja farta } \\
\text { Que essa casa seja santa } \\
\text { Que o perdão seja sagrado } \\
\text { Que a fé seja infinita } \\
\text { Que o homem seja livre } \\
\text { Que a justiça sobreviva } \\
\text { Assim como os três reis magos } \\
\text { Que seguiram a estrela guia } \\
\text { A bandeira segue em frente } \\
\text { Atrás de melhores dias } \\
\text { "Atrás de melhores dias } \\
\text { a bandeira segue em frente } \\
\text { Atrás de melhores dias } \\
\text { a bandeira segue em frente } \\
\text { Êêê" } 37\end{array}$ & $\begin{array}{c}\text { Não Tardará (126) } \\
\text { À terra, em breve, virá a paz. } \\
\text { Preso e encerrado será Satanás. } \\
\text { Sombras e mágoas irão para trás } \\
\text { Quando Jesus regressar! } \\
\text { A Cidade Celestial (5663) } \\
\text { Tenho lido dos belos palácios } \\
\text { Que Jesus foi no céu preparar, } \\
\text { Onde os santos fiéis, para sempre, } \\
\text { Mui felizes irão habitar; } \\
\text { Nem tristeza nem dor nem velhice } \\
\text { Veremos no lar paternal; } \\
\text { Mas metade da glória celeste } \\
\text { Jamais se contou ao mortal. } \\
\text { Hei de vê-lo (566) } \\
\text { Pelas portas eternas, triunfante eu entrarei; } \\
\text { Dor e morte ali não mais me seguirão, } \\
\text { E no lar divinal eternamente ficarei } \\
\text { Com Jesus gozando a grande redenção. }\end{array}$ \\
\hline
\end{tabular}

${ }^{36}$ A música "Bandeira do Divino" escrita por Vitor Martins e Ivan Lins em 1978, traz uma fusão de letras que remete as antigas tradições luso-açorianas. A letra trata sobre a sensação dos devotos em receber a visita da bandeira do Divino Espírito Santo em suas casas, despertando atos de caridade, também recontando fatos da história de Jesus, como o seu nascimento e ressurreição.

${ }^{37}$ Versos da Folia do Divino de Paraty, RJ. 


\begin{tabular}{|c|c|c|}
\hline Características & $\begin{array}{c}\text { Músicas da Festa do } \\
\text { Divino }\end{array}$ & Músicas do Salmos e Hinos \\
\hline $\begin{array}{c}\text { Ação do } \\
\text { Espirito Santo }\end{array}$ & $\begin{array}{c}\text { Ó Vinde } \\
\text { Ó vinde em nós Espírito Santo } \\
\text { do céu vossa luz nos mandai } \\
\text { Ó vinde inspirar nosso canto } \\
\text { A nossa frágil e confiança } \\
\text { animai } \\
\text { Abrasai em divinas chamas (2x) } \\
\text { Inflamai em celeste ardor } \\
\text { Os nossos corações almas } \\
\text { No mais ardente e no mais puro } \\
\text { amor (2x) } \\
\text { Ó vinde ó rico pai dos pobres } \\
\text { e dos fracos reparador } \\
\text { São débeis sem vós os mais } \\
\text { fortes } \\
\text { De todos sois amparo, Pai e } \\
\text { protetor. } \\
\text { Abrasai em divinas chamas (2x) } \\
\text { Inflamai em celeste ardor } \\
\text { Os nossos corações almas } \\
\text { No mais ardente e no mais puro } \\
\text { amor (2x)38 } \\
\text { “O Divino Espírito Santo } \\
\text { Abençoe a nossa gente, } \\
\text { O Divino Espírito Santo } \\
\text { Abençoe a nossa gente } \\
\text { Êêê”39 }\end{array}$ & $\begin{array}{c}\text { Suplicas ao Espírito Santo (215) } \\
\text { Divino Espírito, convém ao Teu auxílio } \\
\text { recorrer. } \\
\text { Manancial de todo o bem, encher-nos vem } \\
\text { com o Teu poder. } \\
\text { E com celestial amor guiar os que Te } \\
\text { querem adorar. } \\
\text { Invocação ao Espírito Santo (217) } \\
\text { Vem como o fogo arder e todo o mal } \\
\text { queimar; as almas frias aquecer, ensina-nos } \\
\text { a amar. } \\
\text { Como óleo vem ungir um povo só em Ti, E a } \\
\text { todos nós fazer sentir a Tua graça aqui. } \\
\text { Oração ao Espírito Santo (218) } \\
\text { Ó divino preceptor! } \\
\text { Bom, fiel Consolador! } \\
\text { Faze agora em todos nós } \\
\text { Poderosa a Tua voz! }\end{array}$ \\
\hline Solidariedade & $\begin{array}{c}\text { A Bandeira do Divino } \\
\text { “A bandeira do Divino } \\
\text { É entregue em vossas mãos, } \\
\text { Queira dar uma esmola, } \\
\text { Pra ganhar a salvação } \\
\text { "O Divino Espírito Santo } \\
\text { É o Senhor da Salvação } \\
\text { Ele pede um agasalho } \\
\text { Pra Ele e seu folião"4o. }\end{array}$ & $\begin{array}{l}\text { Serviço do crente (440) } \\
\text { Vamos nós trabalhar, e os famintos fartar: } \\
\text { Para a fonte os sedentos depressa levar! }\end{array}$ \\
\hline
\end{tabular}

Fontes: ROCHA, 1975. E também Hinos usados na Festa do Divino Espírito Santo em São Luis, MA, Paraty, RJ e nos Açores, Portugal.

\footnotetext{
${ }^{38}$ Hinos usados na Festa do Divino em São Luis do Maranhão, MA.

${ }^{39}$ Versos da Folia do Divino em Paraty, RJ.

${ }^{40}$ Versos da Folia do Divino em Paraty, RJ.
} 
Nesta breve comparação entre as músicas utilizadas ou inspiradas nas Festas do Divino Espírito Santo com os hinos protestantes podemos observar elementos em comum presentes: a ação do Espírito Santo (na promoção do reino messiânico), a solidariedade (vida em família no reino messiânico), a volta de Cristo (para iniciar o reino messiânico), a crença no milênio (o reino messiânico), e, a felicidade futura (fim do sofrimento no reino messiânico).

Outro fator interessante é a quantidade de hinos que tratam da felicidade na vida após a morte, colocando o fiel protestante como um peregrino neste mundo, onde enfrenta sofrimentos, mas com a certeza de que tudo é transitório e será recompensado na chegada ao seu destino: a pátria celestial. Numa espécie de transformação do mito Guarani da terra sem males que faz dele um nômade constante, o fiel protestante torna-se também um nômade, não em busca de uma terra física, mas de um destino inalcançável neste mundo. Esta perspectiva é trazida pelos missionários norte-americanos, impregnados dos ideais puritanos, sob influência dos escritos do puritano John Bunyan. Um bom exemplo é o hino 501 - Oração do Peregrino.

José Eduardo Franco, em estudo sobre o profetismo em Portugal já havia percebido a relação entre o profetismo/messianismo judaico sendo transposto para o profetismo cristão: "Oficialmente, o profetismo bíblico encontra eco no profetismo eclesial: os cristãos também se entendem em diáspora (Igreja Peregrina) e aguardam, em jubilosa esperança, a derradeira vinda de Cristo salvador.” (FRANCO, 2010, p. 154). Para este autor, o profetismo já em Portugal seria o fruto da fusão de três correntes: hebraica, cristã e política, tornando o povo português um grupo que está sempre na expectativa de uma grande mudança.

Esta perspectiva de vida em constante espera recebeu a mensagem protestante e reinterpretou-a para uma espera cuja realização se dará na esfera celestial, após a morte ou após a volta de Cristo. 
Podemos perceber esta perspectiva de peregrinos na terra em busca da pátria celestial em hinos como os transcritos abaixo no Quadro 2:

\section{Quadro 2 - Alguns dos Hinos dos "Salmos e Hinos" com a temática de peregrinação}

\begin{tabular}{|c|c|}
\hline $\begin{array}{l}\text { A mensagem real (303) } \\
\text { Sou forasteiro aqui; em terra estranha estou: } \\
\text { Celeste pátria, sim, anunciando vou. } \\
\text { Embaixador, por Deus, de reinos de além céus, } \\
\text { Venho em serviço do meu Rei. }\end{array}$ & $\begin{array}{l}\text { Promessa bendita (389) } \\
\text { Peregrinando por sobre os montes, } \\
\text { Dentro dos vales, sempre na luz, } \\
\text { Cristo promete nunca deixar-me: } \\
\text { "Eis-me convosco", disse Jesus. }\end{array}$ \\
\hline $\begin{array}{l}\text { Descanso no Céu (560) } \\
\text { Desta vida no deserto, } \\
\text { Peregrino eu ando aqui; } \\
\text { Mas, embora o passo incerto, } \\
\text { Ó Jesus, confio em Ti” }\end{array}$ & $\begin{array}{l}\text { Jornada do crente (493) } \\
\text { Guia, ó Deus, minha sorte, } \\
\text { Nesta peregrinação; } \\
\text { Frágil sou, mas Tu és forte; } \\
\text { não me largue a Tua mão. }\end{array}$ \\
\hline $\begin{array}{l}\text { Guardado em Jesus (489) } \\
\text { Para a Pátria, então irei } \\
\text { Caminhando, sem temor. } \\
\text { Para sempre habitarei, } \\
\text { Bem guardado em Ti, Senhor! }\end{array}$ & $\begin{array}{c}\text { Vou a pátria (589) } \\
\text { Vou à Pátria, eu, peregrino. } \\
\text { A vive eternamente com Jesus. } \\
\text { Oh! Alegria, feliz destino } \\
\text { Por Deus firmado comigo sobre a cruz. }\end{array}$ \\
\hline $\begin{array}{l}\text { Vou para o céu (590) } \\
\text { Vivo aqui como estrangeiro; vou para o Céu! } \\
\text { Este mundo é passageiro; vou para o Céu! } \\
\text { De perigos estou cercado, de tristezas e pecado, } \\
\text { Mas Jesus me tem chamado; Vou para o Céu! }\end{array}$ & $\begin{array}{c}\text { Bela terra (585) } \\
\text { Na terra abençoada estou, } \\
\text { Por Beulah peregrino vou. } \\
\text { Delícias abundantes são } \\
\text { As que do céu desejo dão. }\end{array}$ \\
\hline
\end{tabular}

Fonte: ROCHA, 1975.

As circunstâncias propícias para a mentalidade milenarista existente no mundo rural pela expropriação religiosa e econômica, foram de certa forma aproveitadas pelos missionários protestantes, amoldando-se às crenças préexistentes, gestadas na formação do povo brasileiro. O caipira brasileiro, filho da miscigenação cultural e biológica, traz em si forjadas na alma a crença no sebastianismo, na terra sem males e no pré-milenismo. Assim, a própria condição social e religiosa do homem do campo foi favorável a formação do protestantismo rural que observamos no interior do Brasil. 


\section{Conclusão}

Há claramente uma diferença teológica entre as igrejas protestantes formadas no século XIX nos grande núcleos urbanos e as igrejas formadas nas zonas rurais. Embora a teologia trazida pelos missionários seja a mesma, a ausência da necessessidade de confronto com uma Igreja Católica institucionalizada nas zonas interioranas do país permitiu o surgimento de uma forma de fé mais livre e muito mais próxima das raízes cristãs ibéricas.

As pontas de linha da teologia que chegaram ao culto protestante no Brasil tinham, repito, como trilho-mestre a ideologia dos avivamentos, mas traziam o colorido das multiplas tendências dos diversos estratos missionários. Encontrando aqui um meio social diferente sofreu por sua vez um processo de filtragem que acabou produzindo um protestantismo sui-generis. (MENDONÇA, 1995,p. 205).

Assim é que, no ambiente do interior do país, o catolicismo popular, com sua forte devoção santorial e seu caráter lúdico aliados à ausência de uma liderança oficial, proporcionaram ao protestantismo um ambiente fértil para sua implantação. Este por sua vez, por não prescindir de uma oposição contrastante a um catolicismo oficial, teve a liberdade de se desenvolver mantendo as referências culturais pré-existentes, formando o protestantismo rural.

Nesta modalidade genuinamente brasileira de protestantismo a mensagem racional do protestante se adaptou à crença no sobrenatural, inserindo-a dentro de suas explicações lógicas do universo. Fundindo o imaginário milenarista já presente na cultura caipira com a mensagem da volta de Jesus, surgiram comunidades protestantes que transferem para a vida pós-morte a esperança de dias melhores. Como já antevia o historiador Mendonça (1995, p. 242):

A mensagem protestante canalizada pelos missionários para a camada de homens livres e pobres da população rural constituiu-se num saber (conhecer a Bíblia e os símbolos da fé), numa crença (preceitos éticos e expectação milenarista) e num comportamento piedoso na vida religiosa (cultivo pessoal da fé). As condições próprias do receptor da mensagem, 
dentro da sociedade mais ampla, selecionou e filtrou a mensagem religiosa a partir do seu lugar social e da mentalidade messiânica subjacente formando comunidades micromilenaristas de tipo pré-milenaristas, mais ou menos nômades e de espera.

Uma nova forma de crença surge, forjada no calor dos trópicos, através da união física e espiritual de diversos povos. Da busca dos guaranis pela terra sem males, do sebastianismo e sua esperança de restauração da pátria, e da crença na Era do Espírito Santo regada pela solidariedade, construiu-se uma nova modalidade de fiel: crentes protestantes que se veem como peregrinos na terra, nômades em busca de uma pátria celestial, onde viverão o milênio sem dor, sem sofrimento, governado por Jesus Cristo, que já está sendo divulgado e construído através do Espírito Santo que efetua a religação tanto do homem a Deus como também ao seu próximo através dos laços da solidariedade.

\section{REFERÊNCIAS}

ANDRADE, Mário de. Danças Dramáticas do Brasil. Belo Horizonte: Ed. Itatiaia, 2002.

AUERBACH, Erich. São Francisco de Assis na Comédia de Dante. In: AUERBACH, Erich. Figura. São Paulo: Ática, 1997. p. 65-80.

BÍBLIA SAGRADA. Nova Versão Internacional. São Paulo: Sociedade Bíblica do Brasil, 2001.

BOFF, Leonardo. Atualidade da Experiência de Deus. Petrópolis: Vozes, 1974.

BOSI, Alfredo. Vieira e o Reino deste Mundo. In: VIEIRA, Antônio. De Profecia e Inquisição. Brasília: Senado Federal, 1998. p. 12-44.

BRANDÃO, Carlos Rodrigues. O Divino, o Santo e a Senhora. Rio de Janeiro: Campanha da Defesa do Folclore Brasileiro: FUNARTE, 1978.

CALAFATE, Pedro. Da Origem Popular do Poder ao Direito da Resistência doutrinas políticas no século XVII em Portugal. Lisboa: Esfera do caos, 2012.

CAMÕES. Luis de. Os Lusíadas. Porto: Porto Editora, 2015. Canto 1.

CANDIDO, Antônio. Os Parceiros do Rio Bonito. São Paulo: Duas Cidades, 2001. 
CIDADE, Hernâni; SELVAGEM, Carlos. O Sebastianismo. In: Cultura Portuguesa. Lisboa: Empresa Nacional de Publicidade, 1972. p. 129-138.

CLOUSE, Robert G.(editor). Milênio - significados e interpretações. Campinas: Luz para o Caminho, 1985.

CORREIA, NATÁLIA. O Espírito Santo Feminino. In: CORREIA, NATÁLIA. Espólio de Natália Correia, D9, BNL, Reservados, Manuscrito $n^{\circ}$. 2, caixa 25, folhas 32 e 33, 1999.

COUTO, Ronaldo. Os Jesuítas na América Portuguesa - arranjos e transformações na economia colonial - sec. XVIII. Rio de Janeiro: Editora do Autor, 2013.

DEL PRIORE, Mary Lucy. Festas e Utopias no Brasil Colonial. São Paulo: Brasiliense, 2000.

DRUMMOND, Adriano Lima. Um rei encoberto debaixo dum santo: sebastianismo no "sermão a São Sebastião", de padre Antônio Vieira. Revista do CESP, Belo Horizonte, v. 28, n. 40 - jul.-dez. 2008, p. 53-77.

FRANÇA, Eduardo d'Oliveira. Portugal na época da Restauração. São Paulo: Hucitec, 1997.

FRANCO, José Eduardo. Joaquim de Flora e a sua influência na cultura portuguesa. In: Millenarium - Revista Portuguesa de Ciência das Religiões, Lisboa, Ano I, n. 1, 2002. p. 75-94.

FRANCO, José Eduardo. Profetismo e a Idéia de Nação: modelação religiosa do destino de um povo. In: Religare, Paraíba, v.7, n.2, outubro de 2010, p. 150-163.

FRANCO, José Eduardo; REIS, Bruno Cardoso. O primeiro tratado sobre o Quinto Império Português (1641): Tratado da Quinta Monarquia de Sebastião de Paiva. Portugal, 2004, p. 153-177.

FRIOLI, Adolfo e CAMPOS, Carlos de. João de Camargo de Sorocaba o Nascimento de uma Religião. São Paulo: SENAC, 1999.

GAMEIRO, Aires et alli. Hospitaleiros. In: FRANCO, José Eduardo. Dicionário Histórico das Ordens, Institutos Religiosos e Outras Formas de Vida Consagrada Católica em Portugal. Lisboa: Gradiva, 2010, p. 173-187.

GANDRA, Manuel. Joaquim de Fiore - Joaquimismo e esperança sebástica. Lisboa, Fundação Lusíada, 1999.

GANDRA, Manuel. Sebastianismo. In: Portugal Misterioso. Seleções Reader's Digest, 1998. P. 38-97.

KEMPIS, Thomas. A imitação de Cristo. Lisboa: Editores Reunidos D.L., 1995 [1441]. 
LE GOFF, Jacques. O Nascimento do Purgatório. Lisboa: Editorial Estampa, 1993.

LEFEBVRE, Henri. La Presencia y la Ausencia. Contribuición a la teoria de las representaciones. México: Fondo de Cultura Econômica, 1983.

MACCA, Marcelo; ALMEIDA, Andréa Vilela de. São Sebastião: protetor contra guerras e epidemias. São Paulo: Planeta, 2003.

MARIANO, Neusa de Fátima. Divina Luz nas Águas o Tietê - A festa do Divino Espirito Santo de Laras/SP. Jundiaí: Paco Editorial, 2014.

MARTINS, José de Souza. O Enigma de Paim Vieira. O Estado de São Paulo. Caderno Metrópole 2, p. C-11. São Paulo, 21 de abril de 2007.

MENDONÇA, Antonio Gouvea; VELASQUES FILHO, Procoro. Introdução ao Protestantismo no Brasil. São Paulo: Ed Loyola, 1990.

MENDONÇA, Antonio Gouvea. O Celeste Povir - a inserção do protestantismo no Brasil. São Paulo: ASTE, 1995.

NAVARRO, Eduardo de Almeida. A terra sem mal, o paraíso tupi-guarani. Cultura Vozes, Petrópolis, v. 89, n. 2, março-abril, 1995, p. 61-71.

OLIVEIRA, Rui A. Costa. Dr. Robert Reid Kalley e o estabelecimento do Presbiterianismo em Portugal e no Brasil in: Revista Lusófona de Ciência das Religiões, Lisboa. Ano 5, 2006, n. 9/10, p. 103-123.

PEREIRA DE QUEIROZ, Maria Isaura. O catolicismo Rústico no Brasil in Revista USP, São Paulo, n. 5, 1968. P. 104-128.

PEREZ, Lea Freitas. Festa, religião e cidade: corpo e alma do Brasil. Porto Alegre: Medianiz, 2011.

PIRES, Antônio Machado. Messianismo. In: AZEVEDO, Carlos Moreira (dir.). Dicionário de História Religiosa de Portugal. V. 3. Rio de Ouro: Círculo de Leitores S.A., 2001. P. 195-197.

RIBEIRO, Darcy. O Povo Brasileiro - a formação e o sentido do Brasil. São Paulo: Companhia das Letras, 1995.

RIBEIRO, Lidice Meyer Pinto. Protestantismo Rural - magia e religião convivendo pela fé. São Paulo: Editora Reflexão, 2014.

RIBEIRO, Lidice Meyer Pinto. Protestantismo Rural: um protestantismo genuinamente brasileiro. In: FERREIRA, João Cesário Leonel (org). Novas Perspectivas sobre o

Protestantismo Brasileiro. São Paulo: Paulinas/ Fonte Editorial, 2009, p.189-230. 
ROCHA, João G. da (org.). Salmos e Hinos com Músicas Sacras. Rio de Janeiro: Imprensa Metodista, 1975.

SAEZ, Oscar Calavia. João de Camargo: Sincretismo e Identidades. Revista Ciências Humanas, Florianópolis, v. 16. n. 24, p. 138-153, 1998.

SANCHIS, Pierre. Catolicismo: entre tradição e modernidades. Comunicações do ISER, n. $44,1993$.

SANCHIS, Pierre. Religiões, religião. Alguns problemas do sincretismo no campo religioso brasileiro in. SANCHIS, P. Fiéis e cidadãos: percursos do sincretismo no Brasil. Rio de Janeiro: EdUERJ, 2001, p. 9-57.

VIEIRA, Antônio. A Chave dos Profetas. In: FRANCO, José Eduardo e CALAFATE, Pedro (Dir.) Obra Completa Padre Antônio Vieira, tomo III , Vol. V e VI. Lisboa: Círculo de Leitores, 2014.

VIEIRA, Antônio. Autos do Processo de Vieira na Inquisição. In: FRANCO, José Eduardo e CALAFATE, Pedro (Dir.) Obra Completa Padre Antônio Vieira, tomo III , Vol. IV. Lisboa: Círculo de Leitores, 2014.

VIEIRA, Antônio. Defesa perante o Tribunal do santo Ofício. In: FRANCO, José Eduardo e CALAFATE, Pedro (Dir.) Obra Completa Padre Antônio Vieira, tomo III , Vol. II.

Círculo de Leitores, 2014.

VIEIRA, Antônio. Esperanças de Portugal - Quinto Império do Mundo. São Paulo: Ed. Ática, 2007.

VIEIRA, Antônio. História do Futuro. In: FRANCO, José Eduardo e CALAFATE, Pedro (Dir.) Obra Completa Padre Antônio Vieira, tomo III , Vol.I . Lisboa: Círculo de Leitores, 2014.

VIEIRA, António. Sermão de São Sebastião in: FRANCO, José Eduardo e CALAFATE, Pedro (Dir.) Obra Completa Padre Antônio Vieira, tomo II, Vol. XI - sermões hagiográficos II. Lisboa: Círculo de Leitores, 2014. p. 423-434. 